\title{
Rumo à indexação plena
}

\author{
Toward full indexation
}

\section{Marcio Meirelles*}

O Jornal Vascular Brasileiro foi criado em 2002, ano em que a Sociedade Brasileira de Angiologia e de Cirurgia Vascular (SBACV) completava meio século de existência. E o fato não se deu por acaso.

A Sociedade nascera, em meados do século passado, do empenho de um pequeno número de abnegados especialistas e, embora em constante crescimento, conservara, por muitos anos, um modelo de atuação quase familiar. Era na casa de seus sócios que funcionava e era ali que se guardavam os seus arquivos e o material de secretaria. É natural, portanto, que, até então, não pudesse a Sociedade arcar com as despesas de manutenção de uma revista e que, para divulgar a sua produção científica, devesse valer-se de publicações mantidas por um ou outro de seus dedicados sócios. À altura do cinqüentenário, entretanto, a situação havia mudado. A SBACV crescera significativamente, contava já com cerca de dois mil membros, apresentava uma atividade científica intensa e diversificada e os espaços editoriais que, por generosidade de alguns membros, até então ocupara, já não atendiam às realidades da época.

Decidiu, então, a SBACV assumir os riscos de ter o seu próprio jornal. E de ter um jornal de qualidade; capaz de, no devido tempo, merecer a indexação das mais exigentes instituições. Apostou na competência,

* Ex-Presidente, SBACV.

J Vasc Bras 2007;6(2):109.

Copyright $\odot 2007$ by Sociedade Brasileira de Angiologia e de Cirurgia Vascular no entusiasmo e na participação de seus sócios para a geração de artigos. E no valor da revista. para o seu financiamento. Uma verba foi, desde logo, alocada para garantir ao jornal, sobretudo nos primeiros tempos, sua independência e periodicidade.

É certo que os resultados alcançados pelo Jornal Vascular Brasileiro nesses primeiros cinco anos superaram em muito as expectativas de quase todos os que por ele inicialmente batalharam. Mas, há ainda grandes desafios a vencer. Precisamos redobrar esforços para manter em nível elevado o número e a qualidade da produção científica oferecida a publicação. É, também, indispensável que os membros do Conselho Editorial estejam, a cada dia, mais presentes no exercício de suas relevantes atribuições. E que os nossos sócios, sobretudo os que militam em centros de pesquisa, escolas médicas e universidades, estejam bem atentos para que as regras de pontuação acadêmica vigentes não venham a prejudicar sua indispensável participação nesse esforço do jornal da Sociedade rumo à excelência.

Nesses cinco anos iniciais, já obtivemos vitórias importantíssimas, como as indexações pelo SciELO e pelo Embase. Estamos agora a trabalhar pela indexação na MEDLINE. Este novo patamar, virá, finalmente, garantir ao Jornal Vascular Brasileiro o grau de impacto editorial compatível com a relevância que já detêm a Angiologia e a Cirurgia Vascular brasileiras no concerto científico das nações. 